\title{
Association between Breastfeeding and Deleterious Oral Habits with Development of Malocclusions in Pediatric Dental Patients
}

\author{
Larissa Barreto Barreto, Ricardo Alves Souza, Livia Maria Freitas, Matheus Melo Pithon
}

\begin{abstract}
Purpose: This article evaluates the inter-relationship between the feeding time, presence of deleterious oral habits and the development of malocclusion.
\end{abstract}

\begin{abstract}
Materials and methods: For this purpose, a document focused on the quantitative aspects and was prepared using forms filled out according to the information available in the medical records of 93 children of both genders, aged between 4 and 12 years old, who were treated at the Dental Clinic of UESB (University of the Southwest State of Bahia), J equié Campus, in the period from 2006 to 2009. The Chi-square statistical test was applied.

Results: We observed a higher frequency of children who were naturally breast-fed for a period longer than 6 months (47\%). There was a significant relationship between the shorter duration of breastfeeding leading to deleterious oral habits, and consequently to the development of malocclusion $(p<0.001)$. The existence of one or more deleterious oral habits also favored the development of malocclusion, even in the group that was breast-fed for longer than 6 months $(p<0.001)$. The habit that appeared most frequently was onychophagy (nail biting; $26 \%$ ) followed by lingual interposition (17\%) and pacifier sucking (14\%). The highest prevalence of crowding was found among children with malocclusion (33\%).
\end{abstract}

Conclusion: Mothers should be encouraged to extend the time of breastfeeding and motivate children not to develop deleterious oral habits, as these are crucial factors in diminishing the development of malocclusion.

Keywords: Breastfeeding, Habits, Malocclusion.

How to cite this article: Barreto LB, Souza RA, Freitas LM, $P$ ithon MM. Association between Breastfeeding and Deleterious Oral Habits with Development of Malocclusions in Pediatric Dental Patients. Int J Experiment Dent Sci 2012;1(2):61-66.

\section{Source of support: Nil}

Conflict of interest: None declared

\section{INTRODUCTION}

The benefits of breastfeeding are recognized all over the word, as it meets the baby's requirements and plays an important role in combating infant mortality. It offers advantages, such as perfectly balanced nutrients, immunological functions and psychological development, correct craniofacial growth and in performing physiological activities, such as phonation, mastication and deglutition. In addition, it provides the mother with immense personal fulfillment, through the fundamental relationship of affective exchanges and experience of social contact soon after the baby's birth. ${ }^{1-7}$
Through the movements made to extract milk during breastfeeding (protrusion, retrusion, lifting and lowering the mandible), the development and tonification of the masticatory muscles, ligaments and temporomandibular joint (TM J ) occur, preparing them for the arrival of dentition, and leading to distinct effects on the harmonious growth of the maxillae and dental arches, according to Gimenez et al, $2008^{2}$ and Vigianno et al $2004 .^{8}$

In spite of being a natural act, Radzi and $Y$ ahy $a^{6}$ affirmed that the practice of exclusive breastfeeding is not easy. There are situations in which some mothers are incapable of feeding their babies, or the child is unable to adapt to breastfeeding. Therefore, with the lack of physiological suction at the breast, the baby fails to receive adequate stimulus in the oral-motor-sensory area, and could develop hypotonia of the perioral and lingual musculature, later leading to deformations in the dental arch and palate, harming the functions of mastication, deglutition, respiration and articulation of the sounds of speech. It is worth mentioning that in artificial feeding, that is to say by means of sucking devices and/or feeding bottles, there is a much greater flow of milk than in natural breastfeeding, therefore, the child is nutritionally satisfied in a shorter time with less muscular effort. Whereas the emotional ecstasy of the neural impulse of sucking, present since intrauterine life is not attained, and thus the child tends to seek other means to satisfy itself, such as sucking fingers, pacifiers and objects, which may stimulate the development of deleterious oral habits. 3,7,9-11

Therefore, it has been suggested that there is a significant correlation between the time of natural breastfeeding and the presence of such habits. The longer the period of natural breastfeeding, the less chance there is of a child developing a deleterious sucking habit. 4,7,12-15

The habit is nothing more than the result of repetition of an act with a certain purpose, and over the course of time, it becomes resistant to change. For $V$ aldrighi et $a^{15}$ M oyers, ${ }^{16}$ Silva, ${ }^{17}$ deleterious oral habits may create abnormal forces on the dental arches, contributing to the appearance of a large portion of malocclusions. Nevertheless, for this to occur, the degree of imbalance depends on the triad of Graber, which emphasizes the intensity, frequency of the habit and duration, in addition 
to being influenced by individual predisposition, age, nutritional conditions and the individual's health.

W arren et al, ${ }^{18}$ in their study suggested that there is an even greater risk of developing occlusal problems when the deleterious oral habit persists beyond the time the child is 48 months of age. It is more prudent to break this habit before the child completes 24 months of age.

The M inistry of Health ${ }^{19}$ data points out that at 5 years of age, the prevalence of moderate or severe occlusal habits is around $14.5 \%$ in Brazil. Therefore, the rate of malocclusions is ranked in third position on the scale of priorities and oral health problems in Brazil. Thus, it is observed that the epidemiological status of oral health in this country presents levels of precariousness that deserve attention. ${ }^{20}$

Within this context it is necessary to encourage the discontinuation of deleterious oral habits, in order to prevent possible alterations in dental occlusion, or its progression when has already been established, thus diminishing the number of patients referred for orthodontic treatment. ${ }^{20,21}$ Therefore, it is important to know about and discuss the presentation and etiological factors of these habits in younger populations.

Thus, the present study presents the frequency of malocclusion in children in the age range from 4 to 12 years, attended at the A mbulatory Clinic of the Dentistry Unit of 'U niversidade Estadual do Sudoeste da B ahia' (UESB), and verifies its relationship with the time of breastfeeding and presence of deleterious oral habits in these cases.

\section{MATERIALS AND METHODS}

By means of a documentary study with a quantitative approach, 93 forms were filled out, based on the information available in the medical charts of children aged between 4 and 12 years, with a general mean age of 8.47 years, of both genders, being 61 girls and 32 boys attended at the A mbulatory clinic of the Dentistry U nit at the UESB located on the J equié Campus, in the period from 2006 to 2008, by spontaneous demand for dental treatment.

The form was composed of seven objective questions with respect to the presence or absence of malocclusion and information about the time of exclusive breastfeeding, being classified as: Less than, equal to or longer than 6 months. It was also noted whether or not the children developed deleterious oral habits, and what type they presented. The habits selected for this research were: Finger sucking, pacifier sucking, feeding bottle use, sucking the lips, biting objects, mouth breathing, tongue interposition, bruise, onychophagia (nail biting).

Seventy-six dental charts were discarded, as they did not comply with the correct standard of filling out the anamnesis and clinical exam, causing doubts in interpretation or due to lack of information. The discarded charts also comprised syndromic patients with severe systemic problems and those who had al ready been submitted to orthodontic treatment, which could mask the sample, and patients whose parents did not authorize their participation in the research.

The data found were submitted to descriptive statistical analysis using the Excel program based on percentages. By this method, it was possible to obtain a general overview of the representative values of the sample and comparisons of the most relevant variables found in the research. In addition to the description, the Chi-square test of independence was applied.

The research was conducted in compliance with the criteria established by Resolution CNS 196/96 of the Ministry of Health (B razil, 1996). Thus, the form was only applied after it was approved by the Research Ethics Committee of the 'Universidade Estadual do Sudoeste da Bahia', protocol number 025/2009.

\section{RESULTS}

In the researched sample it was noted that the most frequent age group comprised children from 07 to 11 years (91\%) and 61 of the children were girls (66\%) and 32 were boys $(34 \%)$.

A ccording to the charts filled out with the reports of the persons responsible for the children, it was found that the majority of the children (89\%) were naturally breast-fed, and of these $42 \%$ (39) were fed for a period shorter than or equal to 6 months, and $47 \%$ (44) for a period longer than 6 months. Therefore, only $11 \%$ (10) of the patients were artificially fed (Table 1).

With regard to the duration of breastfeeding time, it could be observed that of the 39 children who were naturally breast-fed for a period shorter than and equal to 6 months, $66.6 \%$ (26) presented sometype of malocclusion and $71.8 \%$ (28) of the children developed one or more deleterious oral habits. The association between the shorter breastfeeding time and development of deleterious habits favored the presence of malocclusion and consequently was statistically significant $(p<0.001)$ (Table 2$)$.

In the group of children, naturally breast-fed for a period longer than 6 months, which comprised 44 children, $70.4 \%$

Table 1: Frequency of groups of children with regard to period of natural breastfeeding

$\begin{array}{lcc}\text { Breastfeeding time } & \mathrm{n} & \% \\ \leq 06 \text { months } & 39 & 42 \\ \geq 06 \text { months } & 44 & 47 \\ \text { Not breast-fed } & 10 & 11\end{array}$


(31) of them presented malocclusion and $65.9 \%$ (29) had a deleterious oral habit. In this group, it was observed that even with the longer time of natural breastfeeding, when there is one or more deleterious oral habits, the devel opment of malocclusion prevails with statistical significance $(p<0.001$; Table 3).

In the smaller group, which comprised children that were not naturally breast-fed $(10 \%), 70 \%$ of the patients presented malocclusion and $70 \%$ had a habit, and no statistically significant association was found $(p=0.13)$ in the development of malocclusion when the deleterious oral habit was developed in this sample (Table 4).

The most frequently found deleterious habits were lingual interposition (17\%), pacifier sucking (14\%) and lastly, bruxism (13\%) and atypical deglutition (13\%) (Graph 1). Other habits investigated, such as use of the feeding bottle, biting lips and objects and mouth breathing were not identified in the sample.

The most frequently found malocclusion was tooth crowding (33\%), followed by anterior and/or posterior crossbite (20\%) and open bite (19\%) (Graph 2).

\section{DISCUSSION}

B reastfeeding is an important natural process that offers irreplaceable advantages to the development of a physically

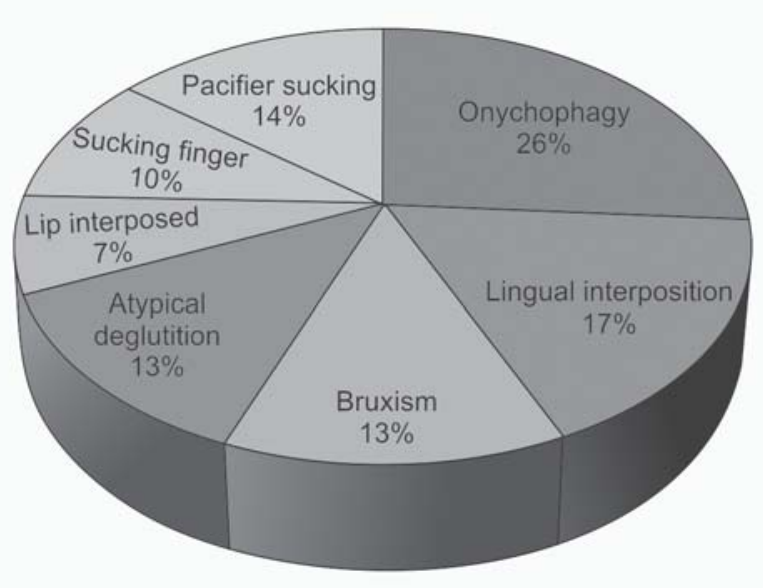

Graph 1: Percentage distribution of deleterious oral habits in the sample studied

and psychologically healthy child. Therefore, it should be encouraged in the first 6 months of life as the child's main source of food, followed by continued breastfeeding for at least 2 years. $^{7}$

In the studied population, a higher percentage (47\%) of children who were breast-fed for a period longer than 6 months was found, in disagreement with the findings of Gimenez et $a l^{2}$ Heringer et $\mathrm{al}^{3}$ and Souza et $\mathrm{al}^{14}$ who obtained higher percentage values of children subjected to

Table 2: Relationship between the presence of deleterious oral habits and malocclusion in the group of children who were breast-fed for the period shorter than or equal to 6 months

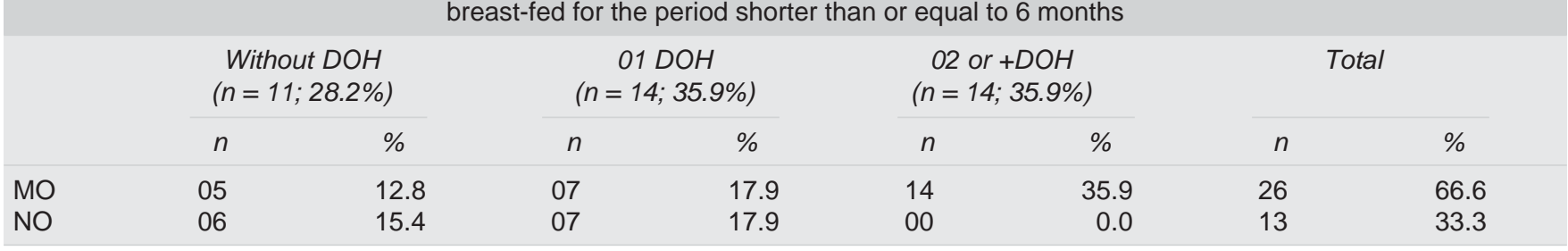

$\mathrm{p}<0.001$ by the Chi-square test; DOH: Deleterious oral habit; MO: Presence of malocclusion; NO: Normocclusion

Table 3: Relationship between the presence of deleterious oral habits and malocclusion in the group of children who were breast-fed for the period longer than 6 months

\begin{tabular}{|c|c|c|c|c|c|c|c|c|}
\hline & \multicolumn{2}{|c|}{$\begin{array}{l}\text { Without DOH } \\
(n=15 ; 34.0 \%)\end{array}$} & \multicolumn{2}{|c|}{$\begin{array}{c}01 \mathrm{DOH} \\
(\mathrm{n}=15 ; 40.9 \%)\end{array}$} & \multicolumn{2}{|c|}{$\begin{array}{c}02 \text { or }+\mathrm{DOH} \\
(\mathrm{n}=15 ; 25.0 \%)\end{array}$} & \multicolumn{2}{|c|}{ Total } \\
\hline & $n$ & $\%$ & $n$ & $\%$ & $n$ & $\%$ & $n$ & $\%$ \\
\hline MO & 07 & 15.9 & 13 & 29.5 & 11 & 25.0 & 31 & 70.4 \\
\hline NO & 08 & 18.2 & 05 & 11.4 & 00 & 0.0 & 13 & 29.6 \\
\hline
\end{tabular}

$\mathrm{p}<0.001$ by the Chi-square test; DOH: Deleterious oral habit; MO: Presence of malocclusion; NO: Normocclusion

Table 4: R elationship between the presence of deleterious oral habit and malocclusion in the group of children who were not breast-fed

\begin{tabular}{|c|c|c|c|c|c|c|c|c|}
\hline & \multicolumn{2}{|c|}{$\begin{array}{l}\text { Without DOH } \\
(n=03 ; 30.0 \%)\end{array}$} & \multicolumn{2}{|c|}{$\begin{array}{c}01 \mathrm{DOH} \\
(\mathrm{n}=03 ; 60.0 \%)\end{array}$} & \multicolumn{2}{|c|}{$\begin{array}{c}02 \text { or }+ \text { DOH } \\
(n=03 ; 10.0 \%)\end{array}$} & \multicolumn{2}{|c|}{ Total } \\
\hline & $n$ & $\%$ & $n$ & $\%$ & $n$ & $\%$ & $n$ & $\%$ \\
\hline MO & 01 & 10.0 & 05 & 50.0 & 01 & 10.0 & 07 & 70.0 \\
\hline NO & 02 & 20.0 & 01 & 10.0 & 00 & 0.0 & 03 & 30.0 \\
\hline
\end{tabular}

$\mathrm{p}<0.001$ by the Chi-square test; DOH: Deleterious oral habit; MO: Presence of malocclusion; NO: Normocclusion 


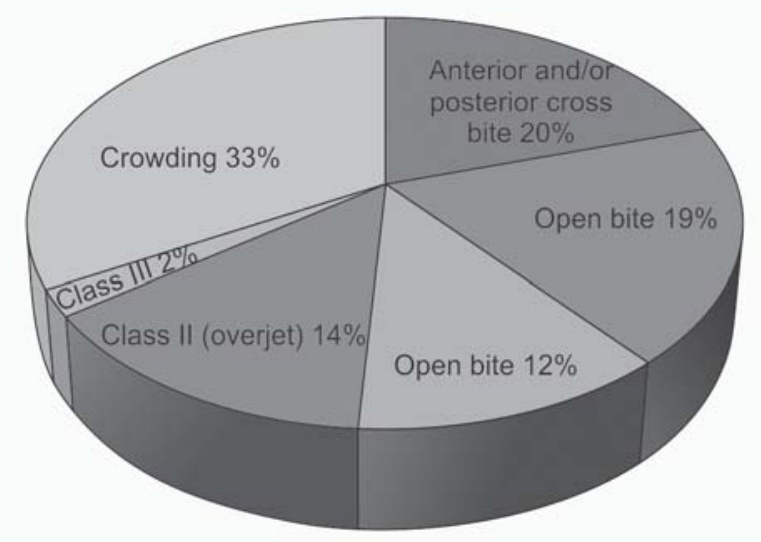

Graph 2: Percentage distribution of malocclusion frequently in the sample

early weaning at 6 months. The percentage for the group of children who were not naturally breast-fed $(10 \%)$ was high when compared with the study of A Imeida et al, ${ }^{1}$ conducted in the State of A mazonas with 560 children, in which only 15 children (2.61\%) were artificially fed, suggesting that this low percentage was due to a cultural question, since the indigenous population is predominant in this region.

In this same connection, it has been observed that weaning in the initial stage of the child's life frequently occurs. Some authors believe that there is a need for guidance with regard to the importance of the practice of natural breastfeeding and an adequate pattern of suction, as a form of prevention against diseases in general and oral health, as well as to promote orofacial development. 1,10,11

The literature has shown that the insufficient duration of natural breastfeeding is associated with the possibility of developing deleterious oral habits. ${ }^{1,7,14,22,23}$ In the present study, $71.8 \%$ of the children breast-fed for a period shorter than or equal to 6 months, presented some type of del eterious oral habit, while in the group of children that were breastfed for a period longer than 6 months, $65.9 \%$ of those analyzed were found to have a deleterious habit.

It was also perceived that a relevant number of children in the total sample acquired a deleterious oral habit (68.8\%), however, a slightly lower number than that related in the studies of A Imeida et al ${ }^{1}$ and Serra-N egra et al ${ }^{7}$ with $75 \%$, M edeiros et al ${ }^{12}$ with $73.6 \%$, L eite-Cavalcanti et $a^{23}$ with $73.4 \%$ and Pereira et al ${ }^{24}$ with $76.47 \%$. It is worth pointing out that $27.9 \%$ (26) of the children in the article in questions developed more than one habit.

When associating the duration of breastfeeding for a period longer than 6 months and the presence of del eterious oral habits, it was verified that the majority of the children developed some type of malocclusion. A lthough a large portion of authors ${ }^{2,5,6,22,23}$ have emphasized that suction at the breast at the time of breastfeeding promotes positive effects on the child's skeletal, muscular and dental development, Pereira et $\mathrm{al}^{2}{ }^{24}$ when analyzing the occlusion of 105 children in day care centers in suburbs on the periphery of Grande Vitória, did not find this significant association. For Cavassani et al, ${ }^{25}$ the etiology of malocclusion is of fundamental importance, because its correction depends on removing the causative factors, in addition to making it easier to recognize the pathology and to apply an objective and effective treatment.

With regard to the prevalence of malocclusions, it was noted that $68.8 \%$ of the studied children presented occlusal alterations; that is, over half the sample. This is a datum similar to that found in the studies of Pereira et $a^{24}$ with $70.85 \%$, Sadakyio et al ${ }^{26}$ with $71.6 \%$, M edeiros et al ${ }^{12}$ with a value equal to $80.2 \%$, Caval canti et al ${ }^{25}$ with $80.6 \%$ and $M$ endes et al $^{4}$ with $92.6 \%$.

During the analysis, it was also perceived that of the $68.8 \%$ (64) children who developed a deleterious oral habit, $79.7 \%$ (51) presented occlusal deviations, a datum even lower than that found by Leite-Cavalcanti et al ${ }^{23}(87 \%)$ and M edeiros et al ${ }^{12}(92.3 \%)$. It should be emphasized that all the children who acquired two or more deleterious oral habits presented malocclusion. Thus, it was verified that there was a higher occurrence of malocclusion in the presence of a deleterious oral habit. 2,7,11,14

However, Pereira et al ${ }^{24}$ found no statistically significant association between the presence of deleterious oral habits and malocclusion. This finding is explained by the fact of malocclusion being multifactorial in nature, and subject to the influence of intrinsic and extrinsic components. Therefore, when bad habits are among the etiologic agents, they are relatively more easily detected and removed, thus reducing the damage they may cause. ${ }^{15,17}$

A s can be seen in Table 4, with reference to the children who were not breast-fed, it was noted that $70 \%$ of them developed one or more deleterious oral habits, a datum similar to that found in the municipal day care centers in the city of Campina Grande - PB by M edeiros et al ${ }^{12}$ with $67.9 \%$. With further reference to this group, it could be observed that $70 \%$ of the sample developed malocclusion.

$B$ ased on the survey, the prevalent deleterious oral habit was onychophagia (nail biting; 26\%), however, according to the literature this habit has no direct relationship with the development of malocclusions. The researched findings point out pacifier sucking as being the most frequent habit. This information is stated in the article by Gimenez et $\mathrm{al}^{2}$ $(50 \%)$, $M$ endes et $\mathrm{al}^{4}(53.7 \%)$, Sousa et all ${ }^{11}(56.3 \%)$, M edeiros et al ${ }^{12}(65.4 \%)$, Serra-N egra et al ${ }^{7}(75.1 \%)$, Souza et al ${ }^{14}(77.9 \%)$, how ever, in the present research this datum was not confirmed, as this habit was ranked in second place. 
Association between Breastfeeding and Deleterious Oral Habits with Development of Malocclusions in Pediatric Dental Patients

\section{Attachment form}

\section{Child's Identification:}

Age: years months

Sex: $\square$ Female

$\square$ Male

1. Person responsible for taking the child to the Dental Unit of UESB
$\square$ Father
$\square$ Mother
$\square$ Other

2. Was the child naturally breast-fed?
$\square$ Yes
$\square$ No

3. The breastfeeding time was shorter than, equal to or longer than 6 months?

$\square$ Period shorter than 6 months

$\square 6$ months

$\square$ Period longer than 6 months

4. Does the child have deleterious oral habits?
$\square$ No, it does not
$\square$ It has one habit
$\square$ Has two or more habits

5. Which deleterious oral habit(s) does the child present?
$\square$ Finger sucking
$\square$ Mouth breathing
$\square$ Pacifier use
$\square$ Feeding bottle use
$\square$ Lingual interposition
$\square$ Biting its lips
$\square$ Bruxism
Biting objects
$\square$ Nail biting
$\square$ others

6 . Does the child present malocclusion?
$\square$ Yes
$\square$ No

7. Which type of malocclusion?

$\square$ Anterior and/or posterior crossbite
$\square$ Open bite
$\square$ Overbite
$\square$ Class II (protrusion)
$\square$ Class III
$\square$ Tooth crowding

Ranked in second and third place, in order of prevalence, the malocclusions crossbite (20\%) and open bite (19\%) were found, which corroborates the research of $\mathrm{C}$ aval canti et al ${ }^{25}$ with schoolchildren in the age range of 6 to 12 years, in the city of Campina Grande/PB, with crossbite $(29.3 \%)$ and open bite $(22.3 \%)$ respectively.

M oreover, researches conducted in the cities of Belo Horizonte/M G and V itória/ES observed that the chance of developing anterior and/or posterior crossbite is four times higher when the child has a deleterious oral habit.,14 $\mathrm{A}$ similar trend was found in the present study. It is also suggested that the presence of a deleterious oral habit is associated with the development of open bite, since $94.7 \%$ of the patients that presented this malocclusion had developed a habit.

In an epidemiological survey of 1,014 children in the age range between 7 and 11 years, in the city of Jequié, conducted by Souza et al ${ }^{14}$ it could also be perceived that $77.7 \%$ of the sample developed malocclusions. This information confirms that the magnitude of occlusal problems in childhood is not restricted to the reality of the public attended at the Dentistry U nit of UESB.

Therefore, providing the mothers with guidance on the importance of breastfeeding could result in prolonging the period of exclusive natural breastfeeding, thereby diminishing the chance of the child acquiring a deleterious oral habit, and consequently developing malocclusion. Furthermore, $V$ aldrighi et al ${ }^{15}$ encourage the use of the orthodontic nipple that is similar to the mother's breast nipple, because it is better adapted to the mouth, and is therefore less harmful than the common rubber nipple.

Based on the above discussion, it is possible to perceive the need for public service to give greater attention to preventive and interceptive actions. In addition, as there was high prevalence of malocclusions and deleterious oral habits, it would be extremely important for orthodontics to be included within the scope of the Dental Specialties Center-CEO (Centro de Especialidades 0 dontológicas). 27,28

\section{CONCLUSION}

- There is evident need to encourage mothers with regard to prolonging natural breastfeeding.

- Natural breastfeeding for an insufficient period is associated with greater possibility of the child developing deleterious oral habits.

- Children's exposure to the effects of deleterious oral habits leads to greater predisposition to developing malocclusions, and this association is intensified when two or more bad habits are present.

- The deleterious habits most frequently found were lingual interposition and pacifier sucking.

- The most frequently found malocclusions were tooth crowding, anterior and/or posterior crossbite and open bite.

\section{REFERENCES}

1. A Imeida MEC, M elo NS, M aia A S, Costa A M M, Souza KR. A influência do desmame precoce no desenvolvimento de hábitos bucais deletérios. Consciência e Saúde 2007;2:227-34.

2. Gimenez CMM, Moraes ABA, Bertoz AP, B ertoz FAB, A mbrosano $G B$. Prevalência de más oclusões na primeira infância e sua relação com as formas de al eitamento e hábitos infantis. Rev Dent Press Ortodon Ortop Facial 2008;2:56-60.

3. Heringer MRC, Reis M, Pereira LFS, Di Ninno CQMS. A Influência da amamentação natural no desenvolvimento dos hábitos orais. Rev CEFAC São Paulo 2005;3:307-10.

4. M endes $A C R$, V alença $A M G$, Lima CCM. A ssociação entre al eitamento, hábitos de sucção não-nutritivos e mal oclusões em crianças de 3 a 5 anos. Cienc Odontol Bras 2008;11:67-75.

5. Peres KG, Barros AJD, Peres MA, Victoria CG. Effects of breastfeeding and sucking habits on malocclusion in a birth cohort study. Rev Saúde Pública 2007;3:34-39. 
6. Radzi Z, Y ahya N A. Relationship between breast-feeding and bottle-feeding to craniofacial and dental development. Annal Dent Univ M alaya 2005;12:9-17.

7. Serra-Negra JMC, Pordeus IA, Rocha Júnior JF. Estudo da associação entre aleitamento, hábitos bucais e maloclusões. R ev Odontol U niv. São Paulo 1997;11:79-86.

8. V iggiano $D$, Fasano $D, M$ onaco $G$, Strohmenger $L$. B reast feeding, bottle feeding, and non-nutritive sucking; effects on occlusion in deciduous dentition. A rch Dis Child 2004;89:1121-23.

9. Carrascoza KC, Possobon RF, Tomita LM, M oraes A BA. Conseqüências do uso da mamadeira para o desenvolvimento orofacial em crianças inicialmente amamentadas ao peito. J Pediatr 2006;5:13-17.

10. Neiva FCB, Cattoni DM, Ramos JLA, Issler H. Desmame precoce: Implicações para o desenvolvimento motor-oral. J Pediatr 2003;79:7-12.

11. Sousa FRN, Taveira GS, Almeida RVD, Padilha WWN . O aleitamento materno e sua relação com hábitos deletérios e maloclusão dentária. Pesqui Bras Odontopediatria Clín Integr 2004:4:211-16.

12. Medei ros PKB, Cavalcanti $A L$, Bezerra PM, M oura C. $M$ aloclusões, tipos de al eitamento e hábitos bucais deletérios em pré-escolares-um estudo de associação. Pesqui B ras Odontopediatria Clín Integr 2005;5:267-74.

13. Natalini $\mathrm{V}$, A ssencio-Ferreira VJ. Relação entre o tempo de amamentação natural e os hábi tos de chupeta, dedo e mamadeira. Rev CEFAC São Paulo 2002;4:141-44

14. Souza DFRK, V alle M A S, Pacheco M CT. Relação clínica entre hábitos de sucção, má oclusão, al eitamento e grau de informação prévia das mães. Rev Dent Press Ortodon Ortop Facial 2006;11(6):81-90.

15. Valdrighi HC, Filho MV, Coser RM, Paula DB, Rezende SE. Hábitos deletérios $X$ Aleitamento materno (sucção digital ou chupeta). RGO 2004;52:237-39.

16. M oyers RE. Etiologia da má oclusão Ortodontia. Rio de J aneiro: Koogan 1991:127-40.

17. Silva EL. Hábitos bucais deletérios. Rev Para M ed 2006;2: 47-50.

18. Warren JJ, Bishara SE, Steinbock KL, Y onezu T, N owak AJ. Effects of oral habits' duration on dental characteristics in the primary dentition. J Am DentA ssoc 2001;132:1685-93; quiz 1726

19. Brasil. Projeto SB Brasil 2003. Condições de saúde bucal da população brasileira 2002-2003. In: Saúde M D, (ed). Brasília 2004:52.

20. Tomita NE, Bijella VT, Franco L. Relação entre hábitos bucais e má oclusão em pré-escolares. Rev Saúde Pública 2000;3: 13-18.

21. Crato NA, Oliveira DV, Cunha TO, M otta AR. Hábitos orais deletérios e relação com aspectos comportamentais e psicológicos de crianças de creches públicas de B elo H orizonte A nais do 70 Encontro de Extensão da Universidade Federal de M inas Gerais B elo Horizonte 2004;1:1-7.
22. Furtado A N M , V edovello Filho M. A influência do período de al eitamento materno na instalação dos hábitos de sucção não nutritivos e na ocorrência de maloclusão na dentição decídua. RGO 2007;4:335-41.

23. L eite-Cavalcanti A, Medeiros-B ezerra PK, Moura C. A leitamento $\mathrm{N}$ atural, A leitamento A rtificial, $\mathrm{H}$ ábitos de Sucção e M aloclusões em Pré-escolares Brasileiros. Rev Saúde Pública Bogotá 2007;2:131-39.

24. Pereira LT, Bussadori SK, Zanetti AL, Höfling RTB, Bueno CES. A valiação da associação do período de amamentação e hábitos bucais com a instalação de más oclusões. RGO 2003;51:203-09.

25. Cavalvanti $A L$, Bezerra PKM, A lencar CRB, Moura C. Prevalência de maloclusão em escolares de 6 a 12 anos de idade em campina grande. Pesq B ras O dontoped Clín Integr 2008;8:99104.

26. Sadakyio CA, Degan VV, Pignataro Neto G, Puppin Rontani RM . Prevalência de má oclusão em pré-escolares de Piracicaba - SP. Cienc Odontol B ras 2004;7:92-99.

27. Souza RA, M agnani MBBA, Nouer DF, Romano FL, Passos $M R$. Prevalence of malocclusion in a B razilian schoolchildren population and its relationship with early tooth loss. B raz J Oral Sci 2008;7:1566-70.

28. Suliano A A, Rodrigues M J, Caldas J únior A F, Fonte PP, PortoCarreiro CF. Prevalência de maloclusão e sua associação com alterações funcionais do sistema estomatognático entre escolares. Cad Saúde Pública 2007;8:14-19.

\section{ABOUT THE AUTHORS}

\section{Larissa Barreto Barreto}

Student of D entistry, D epartment of Orthodontics, Southwest B ahia State U niversity, UESB, Bahia, B razil

\section{Ricardo Alves Souza}

Professor, Department of Orthodontics, Southwest Bahia State University, UESB, Bahia, Brazil

\section{Livia Maria Freitas}

Professor, Department of Orthodontics, Southwest Bahia State University, UESB, Bahia, Brazil

\section{Matheus Melo Pithon}

Professor, Department of Orthodontics, Southwest Bahia State University, UESB, Bahia, Brazil

CorrespondenceAddress A v O távio Santos, 395, sala 705, Centro Odontomédico Dr A Itamirando da Costa Lima, Bairro Recreio CEP 45020-750, Vitória da Conquista, Bahia, B razil, e-mail: matheuspithon@gmail.com 